\title{
PARENTS' LANGUAGE ATTITUDES TOWARDS LANGUAGES AND MAINTENANCE OF HERITAGE LANGUAGE
}

\author{
Sugiyanta \\ English Education Department \\ School of Teacher Training and Education (STKIP) Panca Sakti, West Java \\ Doctoral Degree Program in Applied English Linguistics \\ Atma Jaya Catholic University of Indonesia \\ sugiyanta2711@gmail.com
}

\begin{abstract}
This current research explores parents' language attitudes towards languages and maintenance of heritage language and identifies the efforts of maintaining heritage language and its supporting and inhibiting factors. In this research, a questionnaire and semi-structured interview were employed to collect data. There were 62 respondents, consisting of 37 males and 25 females coming from eleven provinces in Indonesia. Questionnaires were distributed to the respondents by both electronic and direct systems. Respondents were asked to fill in the questionnaires. Interviews were conducted to some respondents. The findings of this research reveal that most parents show positive attitudes towards languages and the maintenance of heritage language. The results also indicate that there were some factors supporting the maintenance of heritage language, including parents' attitudes and roles, community, school, family, daily practices, and culture. In addition, there were a number of factors inhibiting to the maintenance of heritage language such as parents' attitudes and roles, community, school, family, external culture, and technological advancements. In terms of the efforts to maintain the heritage language, the results show that the language should be taught in the families and at schools, and should be used for social interactions and in traditional and ceremonial events.
\end{abstract}

Keywords: parents' language attitudes; language maintenance; heritage language

\section{INTRODUCTION}

Studies of parents' attitudes toward the heritage language maintenance have been conducted by some experts. A study of the parental perceptions on the practices of heritage language maintenance of immigrant parents who reside in the United States or Canada was conducted by Liang (2018). The result indicated that most of the immigrant parents in North America showed positive attitudes toward their children's heritage language learning and maintenance. Factors that inhibited the maintenance of heritage language were related to students' attitudes such as resistance to attend heritage school, and parents' lack of time and energy.

A study of parents' attitudes was also conducted by Budiyana (2017) toward Chinese heritage language maintenance. The study was aimed at exploring the attitudes of Chinese students' parents toward maintaining Chinese heritage language. The result revealed that the weak competencies of the
Chinese parents inhibited the maintenance of the Chinese heritage language. However, they showed positive attitudes toward their children's heritage language maintenance and development.

The other study of parents' attitudes toward home language was conducted by Debnath (2017), focusing on the students of English Medium School of Bangladesh. This study was intended to explore the parents' attitudes toward English, Bangla and local languages as home languages. The data showed that most of the parents had adverse attitude towards their children's use of Bangla and local tongues as home language. However, they had positive attitudes and perspective of the parents towards the maintenance of Bangla language and local languages. Factors that hindered parents' attitudes were related to the institutional pressures and linguistic imperialism existing in their society. Parents were convinced that English was the only key to success in 
academic and career. As a result, they intentionally limited their children to use mother tongues.

Further study of parents' attitudes toward maintaining their heritage language was carried out by LaRotonda (2015). This study was aimed at examining the attitudes of refugee parents and children in terms of maintaining the heritage language. The result indicated that the maintenance of heritage language was an occurrence in both newcomer and not newcomer families. Parents who were interviewed had positive attitudes toward maintaining their heritage language.

The following study of parents' attitudes toward their children's heritage language maintenance was conducted by Becker (2013). This study was a case study of Korean immigrant parents in West Michigan. The main objective was to explore Korean immigrant parents' attitudes toward heritage language maintenance for their children. This result showed that many immigrant parents in the United States struggled with heritage language maintenance as their children started school in the dominant society. They showed strong wishes that heritage language was introduced, talked about, and taught at schools.

A study of Arab American parents' attitudes towards their children's heritage language maintenance and language practices was undertaken by Martin (2009). This study explored the language practices and attitudes towards Arabic of Arab American parents and examined associations between perceived racism and language practices and attitudes. The result showed that parents had positive attitudes towards Arabic and engaged in various language practices that promoted the maintenance of Arabic in their families.

In addition, a study of parents' attitudes was carried out by Park and Sarkar (2007) toward heritage language maintenance for their children and their efforts to help their children maintain the heritage language. The objective of this study was to investigate
Korean immigrant parents' attitudes toward heritage language maintenance for their children and their efforts to help their children maintain Korean as their heritage language. The result revealed that Korean immigrant parents were very positive toward their children's heritage language maintenance. Factors that supported parents' attitudes toward maintaining heritage language were related to their belief that their children's high level of proficiency in the Korean language would help their children keep their cultural identity as Koreans, ensuring them better future economic opportunities.

Based on the results of the above studies, parents have positive attitudes towards the maintenance of heritage language. There were several factors which supported and inhibited the maintenance of heritage language. The supporting factors comprised practical considerations, parents' strong wishes, parents' belief, cultural identity, better future economic opportunities, and more opportunities to make efficient communications. Further, the factors hindering parents' attitudes toward the heritage language maintenance consisted of children's attitudes such as changing language practices, children's resistance to attending heritage language school, parents' lack of time and energy, parents' weak heritage language (Chinese) competencies, institutional pressures and linguistic imperialism existing in their society, and parents' belief.

This current research is to explore the parents' language attitudes towards languages and maintenance of heritage language and to find out the efforts of maintaining heritage language and its supporting and inhibiting factors. It seeks to answer the following research questions: (1) What are the parents' attitudes towards languages and the maintenance of heritage language? (2) What are the factors that affect the maintenance of heritage language: a) What are the supporting and inhibiting factors? and b) What are the efforts to maintain the heritage language?. 
There are several definitions of attitude. Attitude is defined as a favourable or unfavourable evaluative reaction towards something or someone exhibited in one's beliefs, feelings, or intended behaviours (Oundo, Poipoi \& Dinah, 2014). Attitude has cognitive, affective, and conative components. It involves beliefs, emotional reactions, and behavioural tendencies related to the object of the attitude and consists of an underlying psychological predisposition to act or evaluate behaviour in a certain way (Gardner in McGroarty, 1996). Attitude is also defined as an evaluation of an object (Bohner \& Dickel, 2011).

A number of definitions of language attitudes have been proposed by researchers. Language attitude is defined as an attitude which speakers of different language or language varieties have towards each other's language or to their own language. Expressions of positive or negative feelings towards a language may reflect impressions of linguistics difficulty or simplicity, ease or difficulty of learning, degree of importance, elegance, social status etc. (Richards, 1992). Attitude is defined as significant component to understand motives, such as the objectives and goals of language groups in child education planning and types of language behaviour of parents (Ager, 2001). According to Ladegaard (2000), attitude is composed of three parts, including knowledge, emotion and behaviour.

Heritage language is interchangeable with "mother tongue," "native language," and "community language", in the sense that it is a language other than English used by immigrants and their children (Lee \& Shin, 2008). Heritage language refers to any "language other than English and French," and intended to refer to the languages spoken by indigenous (first nation) people or by immigrants (Cummins, 1991). Further, heritage language is a minority language learnt by its speakers at home as children, but it is never fully developed because its speakers grow up with a dominant language in which they become more competent (Valdés, 2000). In addition, heritage language is often defined as a language used in home or familial contexts (Campbell \& Peyton, 1998). Based on the above definitions, heritage language is a language other than the dominant language used and spoken by its speakers in a given social context.

Language maintenance is defined as the survival of a language in a situation where it might be expected to be endangered (Deumert, 2011). There are a number of factors which contribute to the maintenance of heritage language as a linguistic resource in constructing ethnic identities (Fought, 2011). A language can be maintained and preserved when it is considered as an important factor in maintaining a minority's identity. This factor is related to the identity of minority.

\section{METHOD}

This section addresses the method of the research and provides issues of place of the research, respondents, research instrument, data collection technique, and data analysis technique.

This current research was conducted in Jakarta city. There were 62 respondents, consisting of 37 males and 25 females. They from eleven provinces in Indonesia, including Central Java (14), East Java (12), West Java (9), DKI (3), North Sumatra (7), Maluku (2), DIY (5), North Sulawesi (1), East Nusa Tenggara (6), Bangka Belitung (1), and South Sulawesi (2). Their educational backgrounds were composed of high school (23), Dipolma 3 (8), Strata 1 (21) and Strata 2 (10). They consisted of public employees (2), private employees (15), businessmen (18), teachers (11), lecturers (2), pensioner (8), others (6) and were grouped under the age of $30-40$ years (11), 41-50 years (22), 51-60 years (16), $61-70$ years (10) and 71-80 years (3).

Questionnaires and semi-structured interviews were used as the research instruments to collect the data. Questionnaires were distributed to the respondents by both electronic and direct systems, and the respondents were asked to fill in the questionnaires. Interviews were conducted to some respondents. 
To explore parents' attitudes toward languages and maintenance of heritage language, respondents were asked to fill in a questionnaire and to answer interview questions. In the questionnaire, participants were asked to answer to strongly agree to strongly disagree on a four-point Likert scale and were asked to answer open-ended questions. To confirm the data obtained, some respondents were interviewed. They were asked to answer ten interview questions. The data obtained from the questionnaires and interviews were then categorized and analyzed.

\section{RESULT AND DISCUSSION}

This section addresses the findings of the questionnaires and interview questions. Data were collected from 62 parents, consisting of 35 males and 27 females. First, the data from the parents' questionnaire were categorized by using tables and further analyzed and explained. This research was developed on the ground of the following research questions: 1) What are the parents's attitudes towards languages and the maintenance of heritage language? 2) What are the factors that affect the maintenance of heritage language: a) What are the supporting and inhibiting factors? and b) What are the efforts to maintain the heritage language?

\section{Based on the studies of parents' attitudes toward heritage language maintenance, conducted by Liang (2018), Budiyana (2017), Debnath (2017), LaRotonda (2015), Becker (2013), Martin (2009), and Park and Sarkar (2005), parents have positive attitudes towards the maintenance of heritage language.}

The findings of this current research reveal that most parents showed positive attitudes towards languages and the maintenance of heritage language. This finding is in line with the above result.

In reference to the data collected from the questionnaire and interview, the respondent or parents had positive attitudes towards languages. Most of the respondents
(71\%) strongly agreed that language is important to show identity and existence of human being. In terms of their attitudes toward knowing and understanding heritage language, they had different opinions. 39\% of the respondents agreed, $37 \%$ strongly agreed and $24 \%$ disagreed. However, most of them agreed. Related to the use of heritage language, they had very positive attitudes. This could be seen from the respondents answering 'agree', reaching $60 \%$.

Parents positively perceived the need of the teaching of heritage language to the next generation. Based on the data, it was obvious that parents had positive perceptions on the teaching of heritage language, reaching a significant number of $55 \%$ (agree) compared to $45 \%$ (strongly agree). In relation to parents' role in the teaching of heritage language, they perceived positively that parents played a significant role. This could be seen from the points reaching $43 \%$ (strongly agree) and 55\% (agree). Only a slight number (2\%) disagreed. In addition, respondents also positively perceived that they need to teach the heritage language to their children. This was shown by the respondents answering 'strongly agree' (47\%) and 'agree' (50\%).

The following findings were to answer the second research question (RQ2). What are the factors that affect the maintenance of heritage language? a) What are the supporting and inhibiting factors? and b) What are the efforts to maintain the heritage language?

There are a number of factors that generally affect the maintenance of heritage language, including the supporting and inhibiting factors. Park and Sarkar (2005) suggest that factors which contributed to the maintenance of heritage language were related to parents' positive attitudes and parents' belief that maintaining the heritage language would maintain their cultural identity. Liang (2018), Budiyana (2017), and Debnath (2017) propose that factors that inhibited the maintenance of heritage language included child's changing language practices, child's resistance to attending 
heritage language school, parents' lack of time and energy, parents' weak competencies, institutional pressures and linguistic imperialism existing in their society, and so forth.

The findings showed that there were several factors affecting the maintenance of heritage language, including parents' attitudes, child's attitudes, environment, community's attitude, and culture. Parents' attitudes ranked first, followed by environment, culture, child's attitudes, and community attitudes. The result also indicated that there were some factors contributing to the maintenance of heritage language, including parents' attitudes and roles, community, school, family, daily practices, and culture. Parents' attitudes and roles occupied the first place, followed by environment, school, and family. Below is an excerpt from an interview with one of the respondents stating that culture is one of the factors that support the maintenance of heritage language:

“...Faktor-faktor yang mendukung, ya ada Pak, kalau misalnya ya kalau misalnya seperti kita yang hidup di Jakarta, seperti di TMII ada anjungan Jawa Tengah, DIY, mungkin dapat dijadikan sarana untuk pemeliharaan bahasa daerah, dengan adanya pertemuan arisan satu daerah, dengan acara klonengan apa atau apa...".(Ibu Yustina Muryani)

The results show that there are a number of factors inhibiting to the maintenance of heritage language, including parents' attitudes and roles, environment, school, family, external culture, and technological advancements. Parents' attitude and role ranked first, followed by school, environment, external culture, family, and technological advancements. Following is an excerpt from an interview with one of the respondents showing that parents' attitudes and roles, and environment are considered as the factors that inhibit the maintenance of heritage language.

"Faktor itu, misalnya pertama tinggal dalam satu lingkungan tapi heterogen, banyak suku, kedua, ketegasan orang tua, anak tidak bisa berbahasa daerah, orang tua diam saja, tidak ada tabloid bahasa daerah....." (Ibu Yustina Muryani)

Related to the efforts to maintain the heritage language, based on the findings, the language should be taught in the families $(30 \%)$ and at schools (29\%). In addition, the heritage language should be used for social interactions (12\%) and in traditional and ceremonial events (29\%). In general, according to the respondents, the heritage language should be taught first in the families. Following is an excerpt from an interview with one of the respondents confirming that to maintain the heritage language, it should be taught in the family:

“...Kalau menurut saya terutama di lingkungan keluarga, kita sering berkomunikasi dengan bahasa Jawa karena saya dari Jawa, jadi sering berkomunikasi dengan bahasa Jawa dengan istri, anakanak...." (Eko Ari Nurcahyo)

Based on the data collected from the interviews conducted to some respondents, the findings showed that the respondents had positive attitudes toward languages, including the heritage language. There were some factors that influenced the heritage language maintenance, such as parents' attitudes, families, environment, etc. To maintain the heritage language, it is suggested that the language be taught in the families, schools, family meetings, and traditional events.

\section{CONCLUSION}

Based on the above findings and discussion, conclusions can be drawn. Parents have positives language attitudes towards languages and the maintenance of heritage language. There are several factors that affect the maintenance of heritage language. They consist of the supporting factors, including parents' attitudes and roles, community, school, family, daily practices and cultures, and the inhibiting factors, such as parents' attitudes and roles, school, environment, external cultures, family, and technological advancements. In terms of the heritage 
language maintenance, it should be taught in families and schools. In addition, the heritage language should be used in social interactions and traditional and ceremonial events.

Due to the time constraint, a further study should be conducted with a greater number of respondents in order to be more representative and accurate.

\section{REFERENCES}

Ager, D. E. (2001). Motivation in Language Planning and Language Policy. Clevedon: Multilingual Matters Ltd.

Becker, D. J. (2013). Parents' Attitudes toward Their Children's Heritage Language Maintenance: The Case of Korean Immigrant Parents in West Michigan. (Master thesis, Grand Valley State University, USA). Retrieved from http://dspace.ewubd.edu/handle/2525/204 $\underline{5}$.

Bohner, G. \& Dickel, N. (2011). Attitudes and attitude change. Annual Review of Psychology 62(1), pp. 391-417.

Budiyana, Y. E. (2017). Students' Parents' Attitudes toward Chinese Heritage Language Maintenance. Theory and Practice in Language Studies, 7(3), pp. 195-200. Retrived from: http://dx.doi.org/10.17507/tpls.0703.05.

Campbell, R., \& Peyton, J. K. (1998). Heritage language students: A valuable language resource. The ERIC Review, 6(1), 38-39. Retrived from: from http://www.eric.ed.gov/resources/ericrevi ew/vol6no1/heritage.html

Cummins, J. (1991). Introduction. The Canadian Modern Language Review, 47(4), 601-5. Retrived from: https://doi.org/10.3138/cmlr.47.4.FM.

Debnath, A. (2017). Parental attitude to home language: A study on the students of English Medium School of Bangladesh. (Master thesis, East West University, Dhaka). Retrieved from http://dspace.ewubd.edu/handle/2525/204 $\underline{5}$
Deumert, A. (2011). Multilingualism. In The Cambridge Handbook of Sociolinguistics, R. Mesthrie (Editor), pp. 261-282. Cambridge: Cambridge University Press. doi: 10.1017/CBO9780511997068.

Fought, C. (2011). Language and Ethnicity. In The Cambridge Handbook of Sociolinguistics, R. Mesthrie (Editor), pp. 238-257. Cambridge: Cambridge University Press. doi: 10.1017/CBO9780511997068.

Ladegaard, H. (2000). Language Attitudes and Sociolinguistic Behavior: Exploring Attitude Behavior Relations in Language. Journal of Sociolinguistics, 4(2): 214233.

LaRobtonda, A. (2015). Attitudes of Parents and Children Toward Maintaining Their Heritage Language. Retrieved from https://dspace.sunyconnect.suny.edu/bitst ream/handle/1951/66603/LaRotonda_As hley_MastersThesis_Fall2015b_Redacted .pdf? sequence $=4 \&$ is Allowed $=y$

Lee, J. S., \& Shin, S. J. (2008). Korean Heritage Language Education in The United States: The Current State, Opportunities, and Possibilities. Heritage Language Journal, 6(2), 1-20.

Liang, F. (2018). Parental Perceptions toward and Practices of Heritage Language Maintenance: Focusing on the United States and Canada. International Journal of Language Studies, 12(2), pp. 65-86.

Martin, N. (2009). Arab-American Parents' Attitudes toward Their Children's Heritage Language Maintenance and Language Practices. Retrieved from https://doi.org/10.17615/xj87-vn83.

McGroarty, M. (1996). Language Attitudes, Motivation, and Standards. In Sociolinguistics and Language Teaching, S. McKay \& N. H. Hornberger (Eds.), pp. 3-46. New York, NY: Cambridge University Press

Oundo, E. N., Poipoi, M. W., \& Dinah, S. (2014). Relationship between Parents' Attitude towards Educational Involvement and Academic Performance 
of Day Secondary School Students in Samia - Kenya. International Journal of Human Resource Studies, 4(3), pp. 147157. doi:10.5296/ijhrs.v4i3.5964

Park, S. M., \& Sarkar, M. (2007). Parents' Attitudes toward Heritage Language Maintenance for Their Children and Their Efforts to Help Their Children Maintain The Heritage Language: A Case Study of Korean-Canadian Immigrants. Language, Culture and Curriculum, 20(3), 223-235.
Richards, J. C., Platt, J. \& Platt, H. (1992). Longman Dictionary of Language Teaching and Applied Linguistics ( $2^{\text {nd }}$ ed.) United Kingdom: Longman.

Valdés, G. (2000). The Teaching of Heritage Languages: An Introduction for SlavicTeaching Professionals. In The learning and teaching of Slavic languages and cultures, Olga Kagan and Benjamin Rifkin (eds.), 375-403. Bloomington, IN: Slavica.

http://dx.doi.org/10.2167lcc337.0. 


\section{A. Pendapat atau pandangan tentang Bahasa Jawa}

\begin{tabular}{|c|c|c|c|c|c|}
\hline No & Pendapat tentang Bahasa Jawa & $\begin{array}{l}\text { Sangat } \\
\text { Sutuju }\end{array}$ & Setuju & $\begin{array}{l}\text { Tidak } \\
\text { Setuju }\end{array}$ & $\begin{array}{l}\text { Sangat } \\
\text { Tidak } \\
\text { Setuju }\end{array}$ \\
\hline 1. & $\begin{array}{l}\text { Bahasa Jawa sangat penting sebagai } \\
\text { identitas dan keberadaan saya } \\
\text { sebagai manusia. }\end{array}$ & $\begin{array}{c}37 \\
(69.81 \%)\end{array}$ & $\begin{array}{c}16 \\
(30.18 \%)\end{array}$ & & \\
\hline 2. & $\begin{array}{l}\text { Saya perlu mengetahui, memahami } \\
\text { dan menguasai Bahasa Jawa. }\end{array}$ & $\begin{array}{c}25 \\
(47.16 \%)\end{array}$ & $\begin{array}{c}27 \\
(50.94 \%)\end{array}$ & $\begin{array}{c}1 \\
(1.88 \%)\end{array}$ & \\
\hline 3. & $\begin{array}{l}\text { Saya perlu menggunakan Bahasa } \\
\text { Jawa dalam keluarga. }\end{array}$ & $\begin{array}{c}16 \\
(30.18 \%)\end{array}$ & $\begin{array}{c}33 \\
(62.26 \%)\end{array}$ & $\begin{array}{c}4 \\
(7.54 \%)\end{array}$ & \\
\hline 4. & $\begin{array}{l}\text { Saya perlu menggunakan Bahasa } \\
\text { Jawa dalam berkomunikasi dengan } \\
\text { anak-anak saya. }\end{array}$ & $\begin{array}{c}8 \\
(15.09 \%)\end{array}$ & $\begin{array}{c}43 \\
(81.13 \%)\end{array}$ & $\begin{array}{c}2 \\
(3.77 \%)\end{array}$ & \\
\hline 5. & $\begin{array}{l}\text { Saya perlu menggunakan Bahasa } \\
\text { Jawa dalam dalam acara-acara } \\
\text { tradisional dan seremonial. }\end{array}$ & $\begin{array}{c}18 \\
(33.96 \%)\end{array}$ & $\begin{array}{c}32 \\
(60.37 \%)\end{array}$ & $\begin{array}{c}3 \\
(5.66 \%)\end{array}$ & \\
\hline 6. & $\begin{array}{l}\text { Saya perlu menggunakan Bahasa } \\
\text { Jawa dalam dalam acara-acara } \\
\text { keluarga. }\end{array}$ & $\begin{array}{c}15 \\
(28.30 \%)\end{array}$ & $\begin{array}{c}36 \\
(67.92 \%)\end{array}$ & $\begin{array}{c}2 \\
(3.77 \%)\end{array}$ & \\
\hline 7. & $\begin{array}{l}\text { Saya memiliki peran penting dalam } \\
\text { mengajarkan Bahasa Jawa kepada } \\
\text { anak-anak saya. }\end{array}$ & $\begin{array}{c}11 \\
(20.75 \%)\end{array}$ & $\begin{array}{c}39 \\
(73.58 \%)\end{array}$ & $\begin{array}{c}3 \\
(5.66 \%)\end{array}$ & \\
\hline
\end{tabular}

\section{B. Pengajaran Bahasa Jawa kepada Anak-anak}

\begin{tabular}{|c|c|c|c|c|c|}
\hline No & Pengajaran Bahasa Jawa & $\begin{array}{l}\text { Sangat } \\
\text { Setuju }\end{array}$ & Setuju & $\begin{array}{l}\text { Tidak } \\
\text { Setuju }\end{array}$ & $\begin{array}{l}\text { Sangat } \\
\text { Tidak } \\
\text { Setuju }\end{array}$ \\
\hline 1. & $\begin{array}{l}\text { Saya perlu memelihara atau } \\
\text { mempertahankan Bahasa Jawa. }\end{array}$ & $\begin{array}{c}32 \\
(60.37 \%)\end{array}$ & $\begin{array}{c}20 \\
(37.73 \%)\end{array}$ & $\begin{array}{c}1 \\
(1.89 \%)\end{array}$ & \\
\hline 2. & $\begin{array}{l}\text { Untuk memelihara Bahasa Jawa, } \\
\text { orang tua perlu mengajarkannya } \\
\text { kepada anak-anak. }\end{array}$ & $\begin{array}{c}25 \\
(47.16 \%)\end{array}$ & $\begin{array}{c}28 \\
(52.83 \%)\end{array}$ & & \\
\hline 3. & $\begin{array}{l}\text { Bahasa Jawa perlu diajarkan } \\
\text { kepada anak-anak. }\end{array}$ & $\begin{array}{c}22 \\
(41.50 \%) \\
\end{array}$ & $\begin{array}{c}30 \\
(56.60 \%) \\
\end{array}$ & $\begin{array}{c}1 \\
(1.89 \%) \\
\end{array}$ & \\
\hline 4. & $\begin{array}{l}\text { Saya perlu mengajarkan Bahasa } \\
\text { Jawa kepada anak-anak saya. }\end{array}$ & $\begin{array}{c}17 \\
(32.07 \%)\end{array}$ & $\begin{array}{c}35 \\
(66.03 \%)\end{array}$ & $\begin{array}{c}1 \\
(1.89 \%)\end{array}$ & \\
\hline 5. & Bahasa Jawa perlu diajarkan & 19 & 33 & 1 & \\
\hline
\end{tabular}




\begin{tabular}{|c|l|c|c|c|c|}
\hline & $\begin{array}{l}\text { kepada anak-anak dalam } \\
\text { keluarga. }\end{array}$ & $(35.84 \%)$ & $(62.26 \%)$ & $(1.89 \%)$ & \\
\hline 6. & $\begin{array}{l}\text { Bahasa Jawa perlu diajarkan di } \\
\text { sekolah. }\end{array}$ & $\begin{array}{c}9 \\
(16.98 \%)\end{array}$ & $\begin{array}{c}13 \\
(24.52 \%)\end{array}$ & $\begin{array}{c}21 \\
(39.62 \%)\end{array}$ & $\begin{array}{c}1 \\
(1.89 \%)\end{array}$ \\
\hline 7. & $\begin{array}{l}\text { Peran orang tua sangat penting } \\
\text { dalam pengajaran Bahasa Jawa } \\
\text { kepada anak-anak. }\end{array}$ & $\begin{array}{c}(42.28 \%) \\
(50.94 \%)\end{array}$ & $\begin{array}{c}(1.89 \%) \\
(1.89 \%)\end{array}$ \\
\hline
\end{tabular}

\section{Kondisi Pengajaran Bahasa Jawa kepada Anak-anak}

\begin{tabular}{|l|l|c|c|c|c|}
\hline No & \multicolumn{1}{|c|}{ Pengajaran Bahasa Jawa } & Sangat Baik & Baik & $\begin{array}{c}\text { Tidak } \\
\text { Baik }\end{array}$ & $\begin{array}{c}\text { Sangat } \\
\text { Tidak } \\
\text { Baik }\end{array}$ \\
\hline 1. & $\begin{array}{l}\text { Pengajaran Bahasa Jawa kepada } \\
\text { anak-anak Jawa kelahiran Jakarta } \\
\text { saat ini. }\end{array}$ & $\begin{array}{c}2 \\
(3.77 \%)\end{array}$ & $\begin{array}{c}17 \\
(32.07 \%)\end{array}$ & $\begin{array}{c}30 \\
(56.60 \%)\end{array}$ & $\begin{array}{c}4 \\
(7.54 \%)\end{array}$ \\
\hline 2. & $\begin{array}{l}\text { Saya mengajarkan Bahasa Jawa } \\
\text { kepada anak-anak saya. }\end{array}$ & $\begin{array}{c}4 \\
(7.54 \%)\end{array}$ & $\begin{array}{c}36 \\
(67.92 \%)\end{array}$ & $\begin{array}{c}12 \\
(22.64 \%)\end{array}$ & $\begin{array}{c}1 \\
(1.89 \%)\end{array}$ \\
\hline
\end{tabular}

\section{Faktor penghambat dan upaya pengajaran Bahasa Jawa kepada Anak- anak}

1. Faktor-faktor penghambat pengajaran Bahasa Jawa kepada anak-anak kelahiran Jakarta.

\begin{tabular}{|c|c|c|c|c|c|}
\hline No & Faktor Penghambat & $\begin{array}{l}\text { Sangat } \\
\text { Setuju }\end{array}$ & Setuju & $\begin{array}{l}\text { Tidak } \\
\text { Setuju }\end{array}$ & $\begin{array}{l}\text { Sangat } \\
\text { Tidak } \\
\text { Setuju }\end{array}$ \\
\hline 1. & $\begin{array}{l}\text { Ketidakpedulian orang tua untuk } \\
\text { mengajarkan Bahasa Jawa kepada } \\
\text { anak-anak. }\end{array}$ & $\begin{array}{c}9 \\
(16.98 \%)\end{array}$ & $\begin{array}{c}28 \\
(52.83 \%)\end{array}$ & $\begin{array}{c}14 \\
(26.41 \%)\end{array}$ & $\begin{array}{c}2 \\
(3.77 \%)\end{array}$ \\
\hline 2. & $\begin{array}{l}\text { Ketidaktertarikan anak untuk } \\
\text { mempelajari Bahasa Jawa. }\end{array}$ & $\begin{array}{c}7 \\
(13.20 \%)\end{array}$ & 29 & $\begin{array}{c}16 \\
(30.18 \%)\end{array}$ & $\begin{array}{c}1 \\
(1.89 \%)\end{array}$ \\
\hline 3. & $\begin{array}{l}\text { Sikap masyarakat yang tidak } \\
\text { mendukung penggunaan Bahasa } \\
\text { Jawa. }\end{array}$ & $\begin{array}{c}6 \\
(11.32 \%)\end{array}$ & $\begin{array}{c}24 \\
(45.28 \%)\end{array}$ & 21 & $\begin{array}{c}2 \\
(3.77 \%)\end{array}$ \\
\hline 4. & $\begin{array}{l}\text { Penggunaan bahasa Indonesia } \\
\text { sebagai alat komunikasi baik di } \\
\text { lingkungan, masyarakat, sekolah, } \\
\text { dan tempat-tempat lainnya. }\end{array}$ & $\begin{array}{c}16 \\
(30.18 \%)\end{array}$ & $\begin{array}{c}28 \\
(52.83 \%)\end{array}$ & $\begin{array}{c}8 \\
(15.09 \%)\end{array}$ & $\begin{array}{c}1 \\
(1.89 \%)\end{array}$ \\
\hline 4. & $\begin{array}{l}\text { Lingkungan yang tidak } \\
\text { mendukung penggunaan Bahasa } \\
\text { Jawa untuk berkomunikasi. }\end{array}$ & $\begin{array}{c}11 \\
(20.75 \%)\end{array}$ & $\begin{array}{c}27 \\
(50.94 \%)\end{array}$ & $\begin{array}{c}12 \\
(22.64 \%)\end{array}$ & $\begin{array}{c}3 \\
(5.66 \%)\end{array}$ \\
\hline 5. & $\begin{array}{l}\text { Pengaruh budaya luar dan budaya } \\
\text { setempat yang mengharuskan }\end{array}$ & $\begin{array}{c}20 \\
(37.73 \%)\end{array}$ & $\begin{array}{c}24 \\
(45.28 \%)\end{array}$ & $\begin{array}{c}9 \\
(16.98 \%)\end{array}$ & \\
\hline
\end{tabular}




\begin{tabular}{|l|l|l|l|l|l|}
\hline penggunaan bahasa Indonesia. & & & & \\
\hline
\end{tabular}

2. Upaya paling tepat untuk mengajarkan Bahasa Jawa kepada anak-anak. (Jawaban bisa lebih dari 1). Sebaiknya Bahasa Jawa diajarkan di :

\begin{tabular}{|c|l|c|c|}
\hline No & \multicolumn{1}{|c|}{ Tempat } & Total & Percentage \\
\hline 1. & Rumah /Keluarga & 53 & $(100 \%)$ \\
\hline 2. & Sekolah & 18 & $(33.96 \%)$ \\
\hline 3. & Tempat Kerja & 6 & $11.32 \%$ \\
\hline 4. & Masyarakat & 19 & $35.8 \%$ \\
\hline 5. & Pertemuan Keluarga & 41 & $77.35 \%$ \\
\hline 6. & Lain-lain & 10 & $18.87 \%$ \\
\hline & (Local community, traditional events, etc) & & \\
\hline
\end{tabular}

